Article

\title{
Intermittent Very High Frequency Plasma Deposition on Microcrystalline Silicon Solar Cells Enabling High Conversion Efficiency
}

\author{
Mitsuoki Hishida ${ }^{1, *}$, Takeyuki Sekimoto ${ }^{2}$, Mitsuhiro Matsumoto ${ }^{3}$ and Akira Terakawa ${ }^{3}$ \\ Received: 11 November 2015; Accepted: 4 January 2016; Published: 13 January 2016 \\ Academic Editor: Alessio Bosio \\ 1 Automotive \& Industrial Systems Company, Panasonic Corporation, Kadoma, Osaka 571-8506, Japan \\ 2 Advanced Research Division, Panasonic Corporation, Seika, Kyoto 619-0237, Japan; \\ sekimoto.takeyuki@jp.panasonic.com \\ 3 Eco Solution Company, Panasonic Corporation, Kaizuka, Osaka 597-0094, Japan; \\ matsumoto.mi@jp.panasonic.com (M.M.); terakawa.akira@jp.panasonic.com (A.T.) \\ * Correspondence: hishida.mitsuoki@jp.panasonic.com; Tel./Fax: +81-50-3380-2095 (ext. 2308)
}

\begin{abstract}
Stopping the plasma-enhanced chemical vapor deposition (PECVD) once and maintaining the film in a vacuum for $30 \mathrm{~s}$ were performed. This was done several times during the formation of a film of i-layer microcrystalline silicon ( $\mu \mathrm{c}-\mathrm{Si}: \mathrm{H})$ used in thin-film silicon tandem solar cells. This process aimed to reduce defect regions which occur due to collision with neighboring grains as the film becomes thicker. As a result, high crystallinity $\left(X_{c}\right)$ of $\mu c-S i: H$ was obtained. Eventually, a solar cell using this process improved the conversion efficiency by $1.3 \%$ (0.14 points), compared with a normal-condition cell. In this paper, we propose an easy method to improve the conversion efficiency with PECVD.
\end{abstract}

Keywords: thin-film silicon tandem solar cell; microcrystalline silicon; amorphous silicon; crystallinity; plasma-enhanced chemical vapor deposition; conversion efficiency

\section{Introduction}

Stable high quality hydrogenated microcrystalline silicon $(\mu \mathrm{c}-\mathrm{Si}: \mathrm{H})$ films which are used in thin-film silicon tandem solar cells have been difficult to make since the quality of $\mu \mathrm{c}-\mathrm{Si} \mathrm{H}$ varies depending on its underlying shape or film thickness [1]. This is because a defective component in the $\mu \mathrm{c}-\mathrm{Si}: \mathrm{H}$ film is affected by transparent conductive oxide (TCO) texture, as the film thickness of the microcrystalline silicon increases [2]. To avoid a defective region being formed and achieve high conversion efficiency (Eff), the surface morphology of TCO was modified to have a blunt angle or rounded shape [3]. Recently, École Polytechnique Fédérale de Lausanne has developed thin-film silicon solar cells with $12.63 \%$ efficiency [4]. Also, as the current maximum value of Eff, the National Institute of Advanced Industrial Science and Technology (AIST) reported the Eff of $12.69 \%$ with a triode plasma-enhanced chemical vapor deposition (PECVD) reactor [5].

As a model of a defective region generated, when $\mu \mathrm{c}-\mathrm{Si}: \mathrm{H}$ is grown from the slope of the texture shape of TCO, a defective region ingenerates at the collided point of each $\mu \mathrm{c}-\mathrm{Si}: \mathrm{H}[6,7]$. A defective region is affected by the underlying shape or the underlying film quality. It has been reported that the defective region consists of vacancies and a low-density amorphous region [2]. Previously, we proposed another factor for the formation of a defective region due to the shadowing effect on incident radicals [2], which should reduce the $X_{c}$ [8].

Beyond that, a defective region also occurs with the continuous deposition film after becoming thicker. This defect region was caused by colliding with the neighboring grains after the film become 
thicker [9]. This is because $\mu c-S i: H$ grows perpendicular to the textured substrate. The reduction in $X_{c}$ was revealed by micro-crystallinity depth profiling measurements $[8,10]$. An $X_{c}$ profiling technique was reported by Choong et al. who measured the $X_{c}$ profiling of the early-stage $(<800 \mathrm{~nm})$ of $\mu c-S i: H$. Therefore, in this report, we aim to reduce the collisions with the neighboring grains by stopping the PECVD once to make the epitaxial $\mu \mathrm{c}-\mathrm{Si}: \mathrm{H}$ film thinner $(>1000 \mathrm{~nm})$. Finally, a high conversion efficiency solar cell can be expected. Since the beginning period of discharge is an unstable process, the value of $X_{c}$ can be expected to decrease if epitaxial growth of $\mu \mathrm{c}-\mathrm{Si}: \mathrm{H}$ is halted by temporarily stopping the PECVD. Impurities which come from the deposition chamber also influence the quality of $\mu \mathrm{c}-\mathrm{Si}: \mathrm{H}$.

As a comparative experiment to reduce the defective region correlating to the film thickness gain, an experiment was carried out. The experimental method is very simple; the plasma-discharge of very high frequency (VHF) PECVD should be stopped once and then the chamber with a vacuum is held for a few seconds (although this process stopped the epitaxial growth of $\mu \mathrm{c}-\mathrm{Si}: \mathrm{H}$, this experimental method is referred to as "SEG"). In the actual experiment, $S E G$, which was done twice or three times, produces an equal thickness during the i-layer deposition. For ease of evaluating $S E G$, all samples were deposited with pulsed-PECVD [11]. This is because the pulsed-PECVD can be expected to reduce the ion-bombardment and short lifetime species [12,13]. Using a different $S E G$ method, characteristic improvement was reported by Urbain et al. [14]. Even though they used a different way of profiling the controlled $\mathrm{SiH}_{4}$, the aim of suppressing the reduction of $X_{c}$ was the same as that of the SEG experiments. In only the experiment where $S E G$ was done twice using the thin-film silicon tandem solar cells, this $X_{c}$ of test cells became higher than that of normal-condition cells, and it did not decrease during the process of forming a thick film as well as the case using $X_{c}$-adjustment layer [8]. Eventually, Eff improved by $1.3 \%$ (0.14 points), $V_{o c}$ by $0.011 \mathrm{~V}$, and $F F$ by 0.002 compared with those for the normal-condition cell.

\section{Experimental Methods}

In this study, actual thin-film silicon tandem solar cells were used for the evaluation of SEG. The structure of these cells was glass/tin oxide $\left(\mathrm{SnO}_{2}\right) / \mathrm{a}-\mathrm{Si}: \mathrm{H}(\mathrm{p}-\mathrm{i}-\mathrm{n}) / \mu \mathrm{c}-\mathrm{Si}: \mathrm{H}(\mathrm{p}-\mathrm{i}-\mathrm{n}) /$ back electrode [15] For TCO, a commercial $\mathrm{SnO}_{2}$-based TCO substrate (Asahi VU, Asahi Glass, Tokyo, Japan) was adopted. $\mu c-S i: H$ and a-Si:H were deposited by plasma-enhanced chemical vapor deposition (PECVD).

Typically, when the $\mu \mathrm{c}-\mathrm{Si}: \mathrm{H}$ is deposited with PECVD, the plasma-discharge power is not stopped before reaching the target thickness. However, in this study, when the thickness reached one-third of $t$ $(t / 3)$ and two-thirds of $t(2 t / 3), S E G$ was done twice, if the total thickness of $\mathrm{i}-\mu \mathrm{c}-\mathrm{Si}: \mathrm{H}$ is $\mathrm{t}(=2300 \mathrm{~nm})$. The evacuation times of $S E G$ were carried out in two modes: $30 \mathrm{~s}$ and $600 \mathrm{~s}$, and these were labeled cells A and B, respectively. This degree of vacuum was under $5 \times 10^{-3}(\mathrm{pa})$. The vacuum time of $30 \mathrm{~s}$ was determined by the time required for the deposition gases $\left(\mathrm{SiH}_{4} / \mathrm{H}_{2}\right)$ to me almost completely eliminated from the chamber. It is due to a return to the default deposition position. The impact of long time exposure of the cell to the vacuum chamber was compared with that for the cell with the 600 s exhaust time (B cells). Only the difference between cell A and cell B influences the impurities while discharge is halted. The structures of a normal-condition cell and a cell made using the SEG cell (cells A and B) are shown in Figure 1.

Additionally, different numbers of $S E G$ experiments were carried out simultaneously. Since $X_{c}$ is correlated with the film thickness, the value of $X_{c}$ changes according to the number of $S E G$. When the thickness reached one-fourth of $t(t / 4)$, two-fourths of $t(2 t / 4)$, and three-fourths of $t(3 t / 4), S E G$ was done three times, if the total thickness of $\mathrm{i}-\mu \mathrm{c}-\mathrm{Si} \mathrm{H}$ is $\mathrm{t}(=2300 \mathrm{~nm})$. One evacuation time of $S E G$ was $30 \mathrm{~s}$, which is the same as for cell A. This was labeled cell C. The degree of vacuum was under $5 \times 10^{-3}(\mathrm{pa})$, which is the same as for cells A and B. Table 1 summarizes these conditions. 


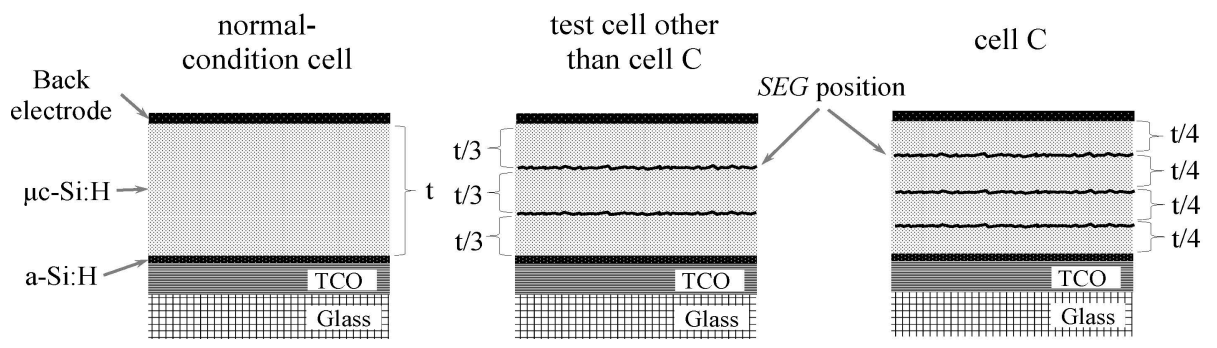

Figure 1. Cell structure comparison between normal-condition, $S E G$ (other than cell C) and a $S E G$ cell (cell C). The i- $\mu \mathrm{c}-\mathrm{Si}: H$ thicknesses were t. SEG was done when the thicknesses reached $t / 3$ and $2 t / 3$, $\mathrm{t} / 4,2 \mathrm{t} / 4$, and $3 \mathrm{t} / 4$.

Table 1. Comparison of i- $\mu \mathrm{c}-\mathrm{Si}: \mathrm{H}$ thickness constitution with normal-condition cells A, B and C; as well as normal-condition film and films A. One time of evacuations times of $S E G$, and total evacuations times of that with films A and cells A, B and C.

\begin{tabular}{ccccc}
\hline Description & $\begin{array}{c}\text { Normal Condition } \\
\text { Cell/Film }\end{array}$ & Cell A/Film A & Cell B & Cell C \\
\hline i-layer constitution & $\mathrm{t}$ & $\mathrm{t} / 3+\mathrm{t} / 3+\mathrm{t} / 3$ & $\mathrm{t} / 4+\mathrm{t} / 4+\mathrm{t} / 4+\mathrm{t} / 4$ \\
total i-later thickness & & $\mathrm{t}(=2300 \mathrm{~nm})$ & 30 \\
exhaust time between i-layer (s) & 0 & 30 & 600 & 90 \\
total exhaust time (s) & 0 & 60 & 1200 & 90 \\
\hline
\end{tabular}

The cell position and temperature of the heater were maintained during SEG. After the SEG, the same gases as the deposition conditions were supplied for $30 \mathrm{~s}$, and then plasma-dischargewas restarted again. The total discharge time of $\mu \mathrm{c}-\mathrm{Si}: \mathrm{H}$ was the same for the whole duration of these experiments, although the discharge was stopped during the deposition. All the $\mu \mathrm{c}-\mathrm{Si}: \mathrm{H}$ treatment times with PECVD became longer by only around $5 \mathrm{~min}$, except for cell $\mathrm{B}$.

Furthermore, to verify the reproducibility of the $S E G$ process, two other types of $S E G$ tests were carried out. These test conditions were different from the conditions applied to cells $A$ to $C$, such as the top layer and $\mathrm{i}-\mu \mathrm{c}-\mathrm{Si}: \mathrm{H}$. However, the SEG processes were carried out twice, the same as for cell A. The total thicknesses of i- $\mu \mathrm{c}-\mathrm{Si}: \mathrm{H}$ were 1500 and $1750 \mathrm{~nm}$ : these were labeled cells D and E, respectively. For cell $\mathrm{D}$, the deposition conditions (thickness, gases, power and pressure) of i- $\mu \mathrm{c}-\mathrm{Si}: \mathrm{H}$ and the top layer condition were varied compared to other cells. Cell $\mathrm{E}$ was subjected to conditions different from those applied to cells A to D. The no-SEG cells were fabricated simultaneously, and were labeled as having been fabricated under the same normal conditions as those for cell $\mathrm{D}$ and cell $\mathrm{E}$. Table 2 summarizes these conditions.

Table 2. Comparison of different i- $\mu \mathrm{c}-\mathrm{Si}: H$ thickness (1500/1750 nm) SEG processes with cell D and normal-condition cell D, and cell E and normal-condition cell E. Single evacuation times of SEG and total exhaust time of cell.

\begin{tabular}{|c|c|c|c|c|}
\hline Description & Normal Condition (D) & Cell D & Normal Condition (E) & Cell E \\
\hline i-layer constitution & $t$ & $t / 3+t / 3+t / 3$ & $t$ & $t / 3+t / 3+t / 3$ \\
\hline total i-later thickness & \multicolumn{2}{|c|}{$\mathrm{t}(=1500 \mathrm{~nm})$} & \multicolumn{2}{|c|}{$\mathrm{t}(=1750 \mathrm{~nm})$} \\
\hline exhaust time between i-layer (s) & 0 & 30 & 0 & 30 \\
\hline tolal exhaust time (s) & 0 & 60 & 0 & 60 \\
\hline
\end{tabular}

The thickness of the i-layer (a-Si:H) in the top layer was sufficient at $240 \mathrm{~nm}$. This was to ensure that the top layer current would have no effect on the bottom layer current, since the bottom layer current has a rate-controlling effect on $I_{s c}$. 
For each condition test, five to eight cells were fabricated. The active area of each cell was $1 \mathrm{~cm}^{2}$. The I-V characteristics of open circuit voltage $\left(V_{o c}\right)$, short circuit current $\left(I_{s c}\right)$, fill factor $(F F)$, and conversion efficiency ( $E f f$ ) were measured using a solar simulator under an air mass of 1.5 (AM 1.5) at $25^{\circ} \mathrm{C}$.

Pulsed PECVD was used at all times during the i- $\mu \mathrm{c}-\mathrm{Si}: \mathrm{H}$ process. As the pulsed PECVD conditions, a PECVD frequency of $40 \mathrm{MHz}$, a pulse modulation frequency of $30 \mathrm{kHz}$, and a duty ratio of $50 \%$ were adopted for i-layer deposition.

For the comparison of $X_{\mathcal{C}}$, actual normal-condition and cell A cells were used in the analysis with a polishing method. This method was reported in [8]. The actual cell A was analyzed by secondary ion mass spectrometry (SIMS) [16]. Nitrogen and oxygen were analyzed through to the glass substrate from the back electrode side of the cell. SIMS measurementing conditions were as follows: Equipment: CAMECA ims5f (CAMECA, Gennevilliers Cedex, France) Ion conditions: Cs+, $14.5 \mathrm{keV}$, approximately $30 \mathrm{nA}$; Measuring area: approximately $30 \mu \mathrm{m}$ diameter; Depth: calibration by Si sputtering.

In addition to the evaluation of cells, $\mu \mathrm{c}-\mathrm{Si}: \mathrm{H}$ films have been analyzed simultaneously. In the film evaluations, Eagle XG (Corning, NY, USA) was used as the substrate. A $20 \mathrm{~nm}$ p-layer was first deposited on a bare substrate under the same conditions as the cell. Then, two types of process (normal-condition and SEG) were carried out at the same thicknesses as for the cell, and these were labeled as normal-condition film and film A. The total $\mu \mathrm{c}-\mathrm{Si}: \mathrm{H}$ thickness of the normal-condition film and film A were " $\mathrm{t}$ ", in the same manner as for the cell. For film A, when the thickness reached one-third of $t(t / 3)$ and two-thirds of $t(2 t / 3), S E G$ processes were done in the same manner as for cell A. The evacuation time of the SEG of film A was $30 \mathrm{~s}$. The i- $\mu \mathrm{c}-\mathrm{Si}: \mathrm{H}$ films of the normal-condition film and the film A were compared. Table 1 summarizes the conditions.

These two types of film (normal-condition film and film A) were analyzed by Raman spectrometry and Fourier transform infrared spectroscopy (FTIR). The quality of the $\mu \mathrm{c}-\mathrm{Si}: \mathrm{H}$ film was different from that of a cell because it is affected by the underlying shape. This evaluation was a relative comparison among the films. To distinguish the crystallinity of the cell expressed by " $X_{c}$ " the crystallinity of the film is referred to as " $X_{c}^{\prime \prime}$ ". The crystallinity of $\mu c-S i: H$ was evaluated using a $514 \mathrm{~nm}$ wavelength and a Via Reflex Raman microscope (Renishaw, Gloucestershire, UK). The crystallinity evaluated by Raman spectroscopy was defined as $X_{c}=I_{520} / I_{480}$, where the peak heights of $\mathrm{I}_{480}$ and $\mathrm{I}_{520}$ are the wavenumbers of 480 and approximately $520 \mathrm{~cm}^{-1}$, respectively $[17,18]$. Fourier transform infrared spectroscopy (FTIR) measurements using the attenuated total reflection (ATR) method were carried out using a Spectrum 100 instrument (PerkinElmer, Waltham, MA, USA) [19]. The following stretching modes (SM) of $\mathrm{Si}-\mathrm{H}$ bonds were used to fit the IR spectra: oxide silicone $\left(\mathrm{O}_{y} \mathrm{SiH}_{x}\right)$ at about $2250 \mathrm{~cm}^{-1}$, high SM (HSM) at $2100 \mathrm{~cm}^{-1}$, middle SM (MSM) at $2040 \mathrm{~cm}^{-1}$, low SM (LSM) at $2000 \mathrm{~cm}^{-1}$, and extremely low SM (ELSM) at 1925 and $1895 \mathrm{~cm}^{-1}$ [20-22]. Each SM was analyzed using the Gaussian mode [23], and each SM fraction was defined as the ratio of the total area of all SMs divided by that SM's area. The LSM was used in the discussion section of this study. The two ELSM values were also simply expressed as ELSM.

\section{Results}

\subsection{Comparison of Conversion Efficiency with the SEG Process Cell}

Test results for the cells A-C are shown in Figure 2 and Table 3. Each of the values of Eff, $V_{o c}, I_{s c}$, and FF in Table 3 was the average for each condition. The error bars are also the standard deviation $(\delta)$ calculated for every condition. All results for the cells (five cells) are plotted in Figure 2. For cell A, Eff improved by $1.3 \%$ ( 0.14 points), $V_{o c}$ by $0.011 \mathrm{~V}, I_{s c}$ by 0.0021 , and $F F$ by 0.002 compared with those for the normal-condition cell. The improved $I_{s c}$ and $F F$ were within a standard deviation range. Simply performing SEG thus improved the Eff, $V_{o c}, I_{s c}$, and $F F$.

For cell B, which has the extended vacuum time, Eff improved by $1.1 \%$ ( 0.12 points), $V_{o c}$ by $0.008 \mathrm{~V}$, $I_{s c}$ by $0.08 \mathrm{~mA}$ compared with those for the normal-condition cell. This result shows that $S E G$ has similar effect to that of cell A. However, no added benefit of Eff is obtained by extending the vacuum 
time. However, $I_{s c}$ was higher than that for cells prepared under other conditions. The longer the vacuum time is, the higher the $I_{s c}$ available is, but the value of the changed $I_{s c}$ resembled the standard deviation range. The result of $F F$ was within the margin of error.

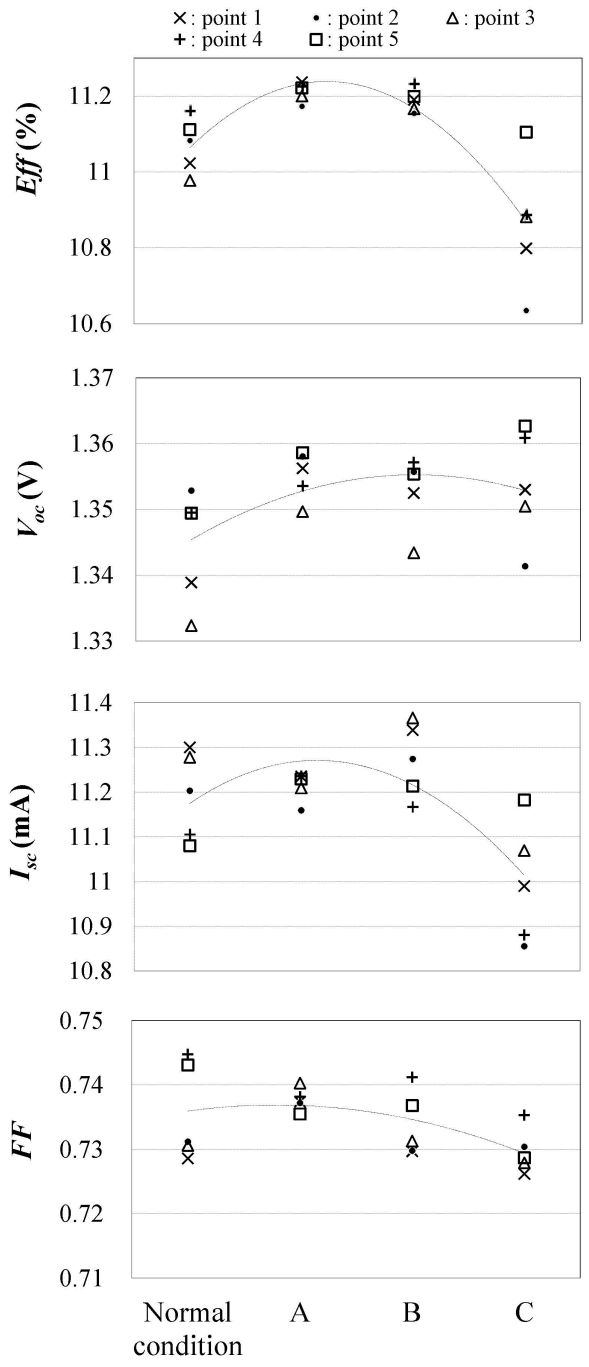

Figure 2. Results of each test cell: normal-condition cell, cell A, cell B, and cell C. For each cell type, five cells were fabricated. Points 1-5 were cells location of substrate.

Table 3. Results for each test cell. Each of the values of Eff, $V_{o c}, I_{s c}$, and FF was averaged for each condition. Error bars are standard deviation $(\delta)$ calculated for each condition.

\begin{tabular}{ccccc}
\hline & Normal-Condition Cell & Cell A & Cell B & Cell C \\
\hline$V_{o c}(\mathrm{~V})$ & $1.345 \pm 0.008$ & $1.355 \pm 0.003$ & $1.353 \pm 0.005$ & $1.354 \pm 0.008$ \\
$I_{S C}(\mathrm{~mA})$ & $11.194 \pm 0.089$ & $11.214 \pm 0.029$ & $11.272 \pm 0.074$ & $10.996 \pm 0.121$ \\
$F F$ & $0.736 \pm 0.007$ & $0.738 \pm 0.002$ & $0.734 \pm 0.005$ & $0.730 \pm 0.003$ \\
$E f f(\%)$ & $11.07 \pm 0.06$ & $11.21 \pm 0.02$ & $11.19 \pm 0.03$ & $10.86 \pm 0.15$ \\
\hline
\end{tabular}

For cell C, which increased the number of SEG treatments to three, Eff decreased by $1.8 \%$ ( 0.21 points), $I_{S C}$ by $0.20 \mathrm{~mA}$ compared with those for the normal-condition cell. Although $V_{o c}$ improved by $0.008 \mathrm{~V}$, it was not better than for cell A. At this time of the experiment, two SEG trials are better than three trials.

Test results for cells D and E are shown in Table 4 and Figure 3. For cell D, Eff increased by $13.1 \%$ (1.14 points), $I_{S C}$ by $1.33 \mathrm{~mA}$, FF by 0.005 compared with the normal-condition cell D. However, 
$V_{o c}$ decreased by $0.027 \mathrm{~V}$. For cell E, Eff increased by $2.1 \%$ ( 0.21 points), $V_{o c}$ by $0.006, I_{s c}$ by $0.31 \mathrm{~mA}$ compared with the normal-condition cell E. But increases of $V_{o c}$ and $I_{s c}$ were within a standard deviation range. However, FF decreased by 0.009 .

Table 4. Results for each test of cell D and cell E. Each of the values of Eff, $V_{o c}, I_{S c}$, and $F F$ was averaged for each condition. Normal condition of D is without SEG. Normal condition of E is without SEG. Error bars are standard deviation $(\delta)$ calculated for each condition.

\begin{tabular}{ccccc}
\hline & Normal Condition (E) & Cell D & Normal Condition (D) & Cell E \\
\hline$V_{o c}(\mathrm{~V})$ & $1.337 \pm 0.015$ & $1.309 \pm 0.021$ & $1.325 \pm 0.009$ & $1.331 \pm 0.005$ \\
$I_{S C}(\mathrm{~mA})$ & $9.099 \pm 0.660$ & $10.424 \pm 0.380$ & $10.289 \pm 0.320$ & $10.597 \pm 0.306$ \\
$F F$ & $0.718 \pm 0.01$ & $0.724 \pm 0.00$ & $0.7335 \pm 0.00$ & $0.724 \pm 0.007$ \\
$E f f(\%)$ & $8.72 \pm 0.49$ & $9.87 \pm 0.167$ & $10.00 \pm 0.213$ & $10.21 \pm 0.278$ \\
\hline
\end{tabular}

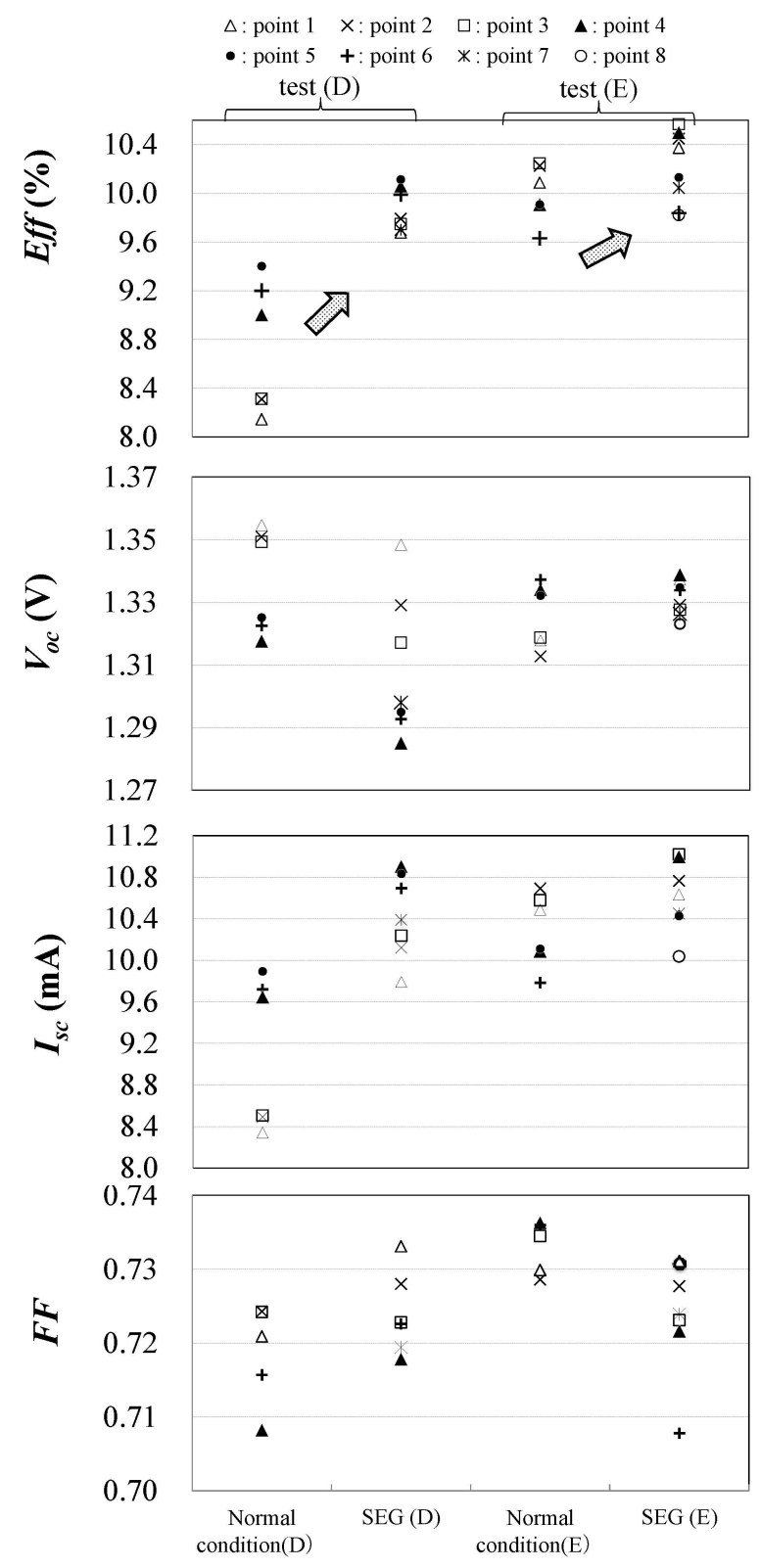

Figure 3. Results of each test cell: cell D, cell E, normal-condition cell D, and normal-condition cell E. For each cell type, eight cells were fabricated. Points 1-8 were cells location of substrate. 
The results for the all $\mathrm{I}-\mathrm{V}$ characteristics are relative to the bottom cell condition, because the thickness of the i-layer (a-Si:H) of the top layer is sufficient. For cell B, for which the thickness of the i-layer on top is $240 \mathrm{~nm}$, the $J_{s c}$ values of the top layer and bottom layer were 11.59 and $11.31 \mathrm{~mA} / \mathrm{cm}^{2}$, respectively, assuming external quantum efficiency (EQE). For cell $\mathrm{D}$, for which the thickness of the top i-layer is $240 \mathrm{~nm}$, the $J_{s c}$ values of the top layer and bottom layer were 11.12 and $9.38 \mathrm{~mA} / \mathrm{cm}^{2}$, respectively, with external quantum efficiency. The bottom layer current has a rate-controlling effect on $J_{s c}$, because a top i-layer thickness of $240 \mathrm{~nm}$ was adequate.

\subsection{Analysis Results of Actual Crystallinity Profile of $\mu c$-Si:H along with Depth}

The Raman analysis results of actual crystallinity profiles of the normal-condition cell and the cell A are shown in Figure 4. The relationship between the film thickness and $X_{c}$ is shown from the $\mu c-S i: H$ thickness of zero. The obtained figure was plotted from the TCO side, and it also includes the thickness of the p-layer. This is because the p-layer of the bottom cell was $\mu \mathrm{c}-\mathrm{Si}: \mathrm{H}$, but its thickness was very small $(20 \mathrm{~nm})$. The values of $X_{c}$ were normalized by the maximum value of $X_{c}$ among the normal-condition cell and the cell A.

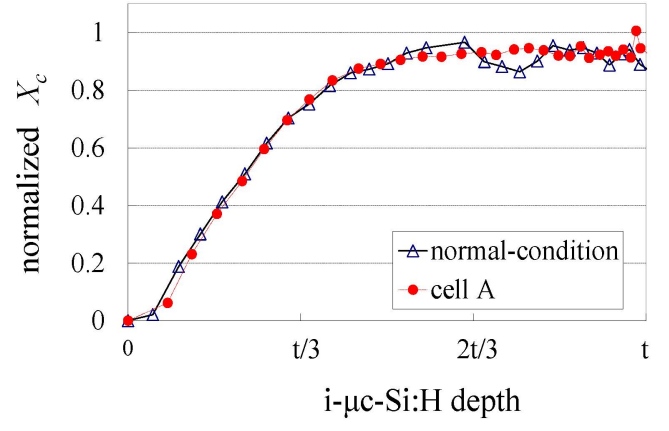

Figure 4. Results of Raman analysis of polished test cells; normal-condition cell and cell A. Values of $X_{c}$ were normalized by the maximum value of $X_{c}$ among normal-condition cell and cell $\mathrm{A}$. $X_{c}$ was expressed from the TCO side.

Both the $X_{c}$ values did not show any difference between the normal-condition cell and the cell A up to the half thickness $(t / 2)$ of $\mu c-S i: H$. However, $X_{c}$ of the normal-condition cell decreased at an around $2 t / 3$. This decrease in $X_{c}$ was probably caused by a defective region produced after the film thickness increased [8]. These decreases in the values of $X_{c}$ were measured at four points successively. The values of $X_{c}$ are connected smoothly, unlike the surrounding values. These decreases in $X_{c}$ are therefore not due to measurement error. The decreasing $X_{c}$ during the formation of a thick film inhibited the high $X_{c}$ of $\mu c-S i: H$ and effected the Eff.

Conversely, there was no reduction in $X_{c}$ in the thickness direction with cell A. It means that SEG has prevented the defective region. In addition, $X_{c}$ increased with the increasing film thickness, and a maximum $X_{c}$ was confirmed. In the comparison of the $X_{c}$ profiles between the normal-condition cell and cell $\mathrm{A}, S E G$ yielded high values of $X_{c}$.

\subsection{Secondary Ion Mass Spectrometry Analyses with Cell}

Nitrogen impurity levels were analyzed with the normal-condition cell and the cell A shown in Figure 5. Since it was analyzed from the back-contact side by SIMS, the results were expressed in the direction reverse to the deposition direction. In the no SEG region of $\mu \mathrm{c}-\mathrm{Si}: \mathrm{H}$, nitrogen was detected by about $2.5 \times 10^{18}\left(\right.$ atom $\left./ \mathrm{cm}^{3}\right)$. Nitrogen increased by approximately $10 \%-15 \%\left(\right.$ about $2.9 \times 10^{18}\left(\right.$ atom $\left.\left./ \mathrm{cm}^{3}\right)\right)$ in the layers of the SEG region: at $t / 3$ and $2 t / 3$. In comparison, under normal conditions, it did not change significantly during the i-layer deposition. Nitrogen gas was never been used at all even after the deposition process in the process chamber. This nitrogen was brought form outside air by the 
substrate of the cell or film, or was released as degassing from the wall of the deposition chamber. Nitrogen gas was incorporated into the $\mu \mathrm{c}-\mathrm{Si}: \mathrm{H}$ [24].

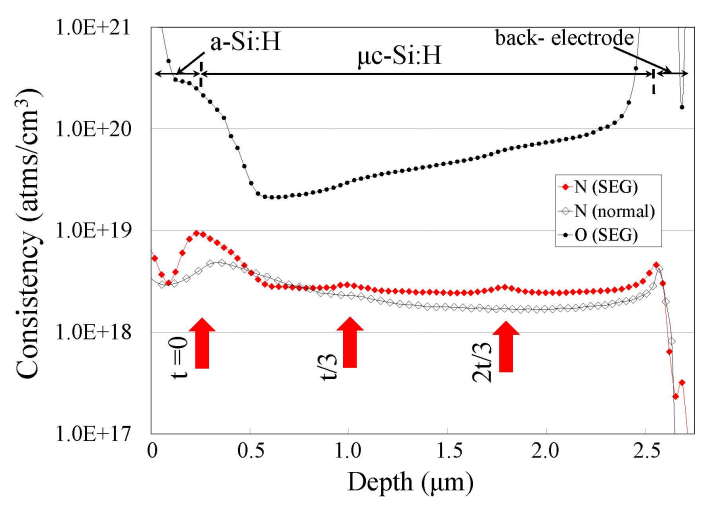

Figure 5. Profile of impurities about nitrogen and oxygen in cell A which used the SEG by SIMS. The nitrogen profile for normal-condition cells is also shown. Results were expressed in the direction reverse to the deposition direction.

On the one hand, between the a-Si:H layer and the $\mu \mathrm{c}-\mathrm{Si}: \mathrm{H}$ layer, nitrogen was detected with a threefold increase $\left(1.0 \times 10^{19}\right.$ atom $\left./ \mathrm{cm}^{3}\right)$ compared to other layers of $\mu \mathrm{c}-\mathrm{Si}: \mathrm{H}$. When the processing equipment was changed from a-Si:H process to $\mu \mathrm{c}-\mathrm{Si}: \mathrm{H}$ process, cells were at once exposed to the atmosphere.

Oxygen impurity levels were analyzed with the cell A shown in Figure 5. Slightly more was detected in the SEG region of $\mu \mathrm{c}-\mathrm{Si}: \mathrm{H}$ in the same way as nitrogen. This was caused by the SEG. However, a difference level comparison between the SEG layer and no SEG layer was not as high as for nitrogen. The details are not noted here because the differences were negligible.

\subsection{Film Analysis with FTIR and Raman}

As a comparison of the normal-condition film and film A, the results of analysis by Raman spectrometry and FTIR are shown in Figure 6. The value of $X_{c}{ }^{\prime}$ was normalized by a maximum value of film A.

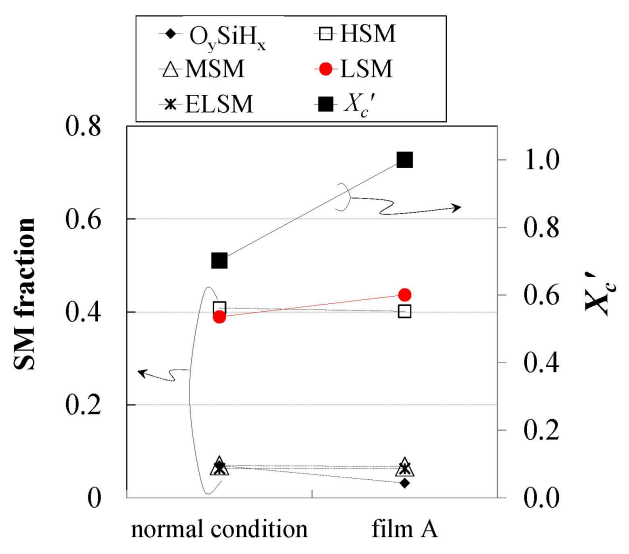

Figure 6. Analyzed results of film tests, normal-condition film and film A, by Raman spectrometry and FTIR. The values of $X_{c}{ }^{\prime}$ were normalized by the value of the film A.

The film quality was different from the quality of the cell because that was deposited on the flat-glass rather than textured-TCO. The difference was spread significantly by the flat substrate. Thus, this confirmation was a relative comparison.

In film A, the LSM value was detected as stronger compared to a normal-condition film. This means that the film A contains a large amount of silicon monohydride ( $\mathrm{Si}-\mathrm{H})$, so this component is expected to 
terminate the dangling bonds in $\mu \mathrm{c}-\mathrm{Si}: \mathrm{H}$ [25]. Also, $\mathrm{O}_{y} \mathrm{SiH}_{x}$ which means crystalline grain boundaries was fewer than in the normal-condition film [19]. Owing to the $S E G$, the quality of $\mu c-S i: H$ became better on the evaluation of the film.

However, $X_{c}{ }^{\prime}$ of film A was higher than that of the normal condition film. The higher $X_{c}{ }^{\prime}$, higher LSM, and lower $\mathrm{O}_{y} \mathrm{SiH}_{x}$ of $\mathrm{i}-\mu \mathrm{c}-\mathrm{Si}: \mathrm{H}$ such as film A can yield a high solar cell Eff. Thus, $S E G$ successfully improved the $\mu \mathrm{c}-\mathrm{Si}: \mathrm{H}$ quality.

\section{Discussion}

To reduce the defective region correlation with the film thickness gain, the $S E G$ process was carried out. Under its influence, as seen in Figure $4, X_{c}$ of $\mu c-S i: H$ does not decrease the value of $X_{c}$ during the process of forming a thick film. As a result, the cell achieved a high $X_{c}$ and the value of $X_{c}{ }^{\prime}$ increased. Also, as seen in Figure 6, the LSM value was detected as stronger than in a normal-condition film. Increasing the amorphous component such as LSM improved the quality of $\mu \mathrm{c}-\mathrm{Si}: \mathrm{H}$ by terminating the dangling bonds in $\mu \mathrm{c}-\mathrm{Si}: \mathrm{H}[26,27]$. Eventually, the Eff, $V_{o c}$, and $F F$ of cell A improved.

On the other hand, the difference between cell A and cell B, which was the test of discharge stop time, increased the $I_{s c}$. This characteristic difference was led not only by the initial discharge instability, but also by the impurity incorporation. Nitrogen and oxygen were also detected on the SEG cell with SIMS. On another hand, the $X_{c}$ of $\mu c-S i: H$ is changed by nitrogen, according to Ehara [28]. In our study of film A, the LSM which corresponds to the amorphous component $(\mathrm{Si}-\mathrm{H})$ was increased using the $S E G$ layer. From this circumstantial evidence, it is reasonable to assume that nitrogen, which comes from the SEG process, increased the amorphous component. More nitrogen in cell B increases the N donor in the amorphous component and may increase the charged Si dangling bonds [29] and finally increased the $I_{S c}$ more than cell A. Or oxygen was increased by $S E G$ impurities in the growing film [30].

After the $S E G$, the amorphous component was deposited in the precursor defective region. The crystalline direction of $\mu \mathrm{c}-\mathrm{Si}: \mathrm{H}$, which grows perpendicular to the textured substrate, was changed by the amorphous component [31]. As a result, collisions with the neighboring grains were reduced. The oxide might have influenced the $X_{c}$ as well as nitrogen [32]. On the another front, a large amount of nitrogen was detected in the earlier thickness stage of $\mu c-\mathrm{Si}: \mathrm{H}$ (around $t=0$ ) in Figure 5 . In exactly the same way, the value of $X_{c}$ became low at its earlier thickness stage (around $t=0$ ) in Figure 4 . More nitrogen, which was carried from outside, might change it.

Moreover, in many of the $S E G$ cell Cs, $V_{o c}$ increased, and $I_{s c}$ and $F F$ decreased. Since the $\mu c-S i: H$ film formation was stopped before the $X_{c}$ growth increases, the continuous deposition time of $\mu c-\mathrm{Si}: \mathrm{H}$ was shortened, and much of the amorphous phase easily formed [8]. Therefore, much of the amorphous phase increased $V_{o c}$ [3], and decreased $I_{s c}$ [33]. Since the shunt resistance was increased by the rising number of $S E G, F F$ was decreased [34].

The other cells (D, E) showed improved Eff, even when certain conditions were changed. These results showed repeatability in how the $S E G$ process improves efficiency. However, variations (increase or decrease) of $V_{o c}, I_{s c}$ and $F F$ did not show the same pattern. Thus, Eff changed depending on each condition. This is because the solar characteristic of $\mathrm{i}-\mu \mathrm{c}-\mathrm{Si}: \mathrm{H}$ are determined by the proportion of $\mu \mathrm{c}-\mathrm{Si}: \mathrm{H}$ and a-Si:H. As a result, the best number for $S E G$ varies depending on the i-layer condition. Double $S E G$ does not always produce a high Eff, even though it showed improvement in this experiment. The number of $S E G s$ can be determined by how high $X_{\mathcal{c}}$ becomes.

\section{Conclusions}

It was considered that stopping the plasma-discharge of PECVD during the deposition cannot generate a high quality film, because it is likely to contain impurities. However, in this study, stopping the plasma-discharge and applying vacuum for $30 \mathrm{~s}$ was done a few times very consciously during the deposition. This was aimed at increasing the $X_{c}$ by avoiding collisions with the neighboring grains after the film became thicker. Then, collisions of $\mu c-\mathrm{Si}: \mathrm{H}$ with each other were suppressed. Additionally, SEG improved the quality of the $\mu \mathrm{c}-\mathrm{Si} \mathrm{H}$ film by increasing the amorphous component. 
Finally, the $X_{c}$ value of holistic $\mu c-S i: H$ became high. As a result, Eff improved by $1.3 \%$ ( 0.14 points), compared with the normal-condition cell. This cell used the $S E G$ process several times during the deposition of $\mathrm{i}-\mu \mathrm{c}-\mathrm{Si}: \mathrm{H}$. The optimal number of $S E G$ applications depends on the conditions of the $\mu c-S i: H$ film. It should be determined by how high $X_{c}$ becomes. $S E G$ is a process that involves simply stopping the plasma discharge of VHF PECVD. It is an easily applied process, the only difference being that the process time is a few minutes longer.

Acknowledgments: This work was in part supported by Yukiharu Uraoka and Yasuaki Ishikawa of Nara Institute of Science and Technology. The authors thank them for constructive discussion.

Author Contributions: In this paper, Takeyuki Sekimoto, Mitsuhiro Matsumoto and Akira Terakawa performed the experiments and collected and analyzed data and gave some useful suggestions for this work and helped revise the manuscript. Moreover, Yukiharu Uraoka and Yasuaki Ishikawa of Nara Institute of Science and Technology gave some useful suggestions for this work.

Conflicts of Interest: The authors declare no conflict of interest.

\section{References}

1. Cuony, P.; Marending, M.; Alexander, D.T.L.; Boccard, M.; Bugnon, G.; Despeisse, M.; Ballif, C. Mixed-phase p-type silicon oxide containing silicon nanocrystals and its role in thin film silicon solar cells. Appl. Phys. Lett. 2010, 97, 213502. [CrossRef]

2. Naruse, Y.; Matsumoto, M.; Sekimoto, T.; Hishida, M.; Aya, Y.; Shinohara, W.; Fukushima, A.; Yata, S.; Terakawa, A.; Iseki, M.; et al. Identification of defective regions in thin-film Si solar cells for new-generation energy devices. In Proceedings of the 38th IEEE Photovoltaic Specialists Conference, Austin, TX, USA, 3-8 June 2012; pp. 003118-003123.

3. Bailat, J.; Domine, D.; Schluchter, R.; Steinhauser, J.; Fay, S.; Freitas, F.; Bucher, C.; Feitknecht, L.; Niquille, X.; Tscharner, T.; et al. High-Efficiency P-I-N Microcrystalline and Micromorph Thin Film Silicon Solar Cells Deposited on LPCVD Zno Coated Glass Substrates. In Proceedings of the 4th World Conference Photovoltaic Energy Conversion, Waikoloa, HI, USA, 7-12 May 2006; Volume 2, pp. 1533-1536.

4. Boccard, M.; Despeisse, M.; Escarre, J.; Niquille, X.; Bugnon, G.; Hanni, S.; Eymard, M.B.; Meillaud, F.; Ballif, C. High-Stable-Efficiency Tandem Thin-Film Silicon Solar Cell With Low-Refractive-Index Silicon-Oxide Interlayer. IEEE J. Photovolt. 2014, 4, 1368-1373. [CrossRef]

5. Matsui, T.; Bidiville, A.; Maejima, K.; Sai, H.; Koida, T.; Suezaki, T.; Matsumoto, M.; Saito, K.; Yoshida, I.; Kondo, M. High-efficiency amorphous silicon solar cells: Impact of deposition rate on metastability. Appl. Phys. Lett. 2015, 106, 053901. [CrossRef]

6. Python, M.; Madani, O.; Dominé, D.; Meillaud, F.; Vallat-Sauvain, E.; Ballif, C. Influence of the substrate geometrical parameter son microcrystalline silicon growth for thin-film solar cells. Sol. Energy Mater. Sol. Cells 2009, 93, 1714-1720. [CrossRef]

7. Despeisse, M.; Bugnon, G.; Feltrin, A.; Stueckelberger, M.; Cuony, P.; Meillaud, F.; Billet, A.; Ballif, C. Resistive interlayer for improved performance of thin film silicon solar cells on highly textured substrate. Appl. Phys. Lett. 2010, 96, 073507. [CrossRef]

8. Hishida, M.; Ueno, H.; Sekimoto, T.; Terakawa, A. Use of microcrystallinity depth profiling in an actual tandem silicon solar cell by polishing to achieve high conversion efficiency. Jpn. J. Appl. Phys. 2015, 54, 052302. [CrossRef]

9. Das, U.; Morrison, S.; Centurioni, E.; Madan, A. Thin film silicon materials and solar cells grown by pulsed PECVD technique. IEE Proc. Circuits Devices Syst. 2003, 150, 282-286. [CrossRef]

10. Choong, G.; Vallat-Sauvain, E.; Multone, X.; Fesquet, L.; Kroll, U.; Meier, J. Measurements of Raman crystallinity profiles in thin-film microcrystalline silicon solar cells. J. Phys. 2013, 46, 235105. [CrossRef]

11. Kimura, H.; Maeda, H.; Murakami, H.; Nakahigashi, T.; Ohtani, S.; Tabata, T.; Hayashi, T.; Kobayashi, M.; Mitsuda, Y.; Nakamura, N.; et al. Study of Deposition Process in Modulated RF Silane Plasma. Jpn. J. Appl. Phys. 1994, 33, 4389-4394. [CrossRef]

12. Kondo, M.; Fujiwara, H.; Matsuda, A. Fundamental aspects of low-temperature growth of microcrystalline silicon. Thin Solid Films 2003, 430, 130-134. [CrossRef]

13. Matsui, T.; Kondo, M. Advanced materials processing for high-efficiency thin-film silicon solar cells. Sol. Energy Mater. Sol. Cells 2013, 119, 156-162. [CrossRef] 
14. Urbain, F.; Smirnov, V.; Becker, J.-P.; Rau, U.; Finger, F.; Ziegler, J.; Kaiser, B.; Jaegermann, W. a-Si:H/ $\mu$ c-Si:H tandem junction based photocathodes with high open-circuit voltage for efficient hydrogen production. J. Mater. Res. 2014, 29, 2605-2614. [CrossRef]

15. Terakawa, A. Review of thin-film silicon deposition techniques for high-efficiency solar cells developed at Panasonic/Sanyo. Sol. Energy Mater. Sol. Cells 2013, 119, 204-208. [CrossRef]

16. Kilper, T.; Beyer, W.; Bräuer, G.; Bronger, T.; Carius, R.; van den Donker, M.N.; Hrunski, D.; Lambertz, A.; Merdzhanova, T.; Mück, A.; et al. Oxygen and nitrogen impurities in microcrystalline silicon deposited under optimized conditions: Influence on material properties and solar cell performance. J. Appl. Phys. 2009, 105, 074509. [CrossRef]

17. Droz, C.; Vallat-Sauvain, E.; Bailat, J.; Feitknecht, L.; Meier, J.; Shah, A. Relationship between Raman crystallinity and open-circuit voltage in microcrystalline silicon solar cells. Sol. Energy Mater. Sol. Cells 2004, 81, 61-71. [CrossRef]

18. Matsui, T.; Tsukiji, M.; Saika, H.; Toyama, T.; Okamoto, H. Correlation between Microstructure and Photovoltaic Performance of Polycrystalline Silicon Thin Film Solar Cells. Jpn. J. Appl. Phys. 2002, 41, 20-27. [CrossRef]

19. Mirabella, F.M., Jr. Internal Reflection Spectroscopy: Theory and Applications; Mirabella, F.M., Ed.; Marcel Dekker, Inc.: New York, NY, USA, 1993.

20. Smets, A.H.M.; Matsui, T.; Kondo, M. High-rate deposition of microcrystalline silicon p-i-n solar cells in the high pressure depletion regime. J. Appl. Phys. 2008, 104, 034508. [CrossRef]

21. Smets, A.H.M.; Matsui, T.; Kondo, M. Infrared analysis of the bulk silicon-hydrogen bonds as an optimization tool for high-rate deposition of microcrystalline silicon solar cells. Appl. Phys. Lett. 2008, 92, 033506. [CrossRef]

22. Smets, A.H.M.; Matsui, T.; Kondo, M.; van de Sanden, M.C.M. The hydride stretching modes of hydrogenated vacancies in amorphous and nanocrystalline silicon: A helpful tool for material characterization. In Proceedings of the 34th IEEE Photovoltaic Specialists Conference, Philadelphia, PA, USA, 7-12 June 2009; pp. 721-724.

23. Yamashita, K.; Minami, S. Evaluation of Numerical Filters for Smoothing Spectroscopic Data. Jpn. J. Appl. Phys. 1969, 8, 1505-1512. [CrossRef]

24. Quach, N.T.; Reif, R. Solid phase epitaxy of polycrystalline silicon films: Effects of ion implantation damage. Appl. Phys. Lett. 1984, 45, 910-912. [CrossRef]

25. Kondo, M.; Fukawa, M.; Guo, L.; Matsuda, A. High rate growth of microcrystalline silicon at low temperatures. J. Non-Cryst. Solids 2000, 266-269, 84-89. [CrossRef]

26. Xu, L.; Li, Z.P.; Wen, C.; Shen, W.Z. Bonded hydrogen in nanocrystalline silicon photovoltaic materials: Impact on structure and defect density. J. Appl. Phys. 2011, 110, 064315. [CrossRef]

27. Wen, C.; Xu, H.; He, W.; Li, Z.; Shen, W. Tuning oxygen impurities and microstructure of nanocrystalline silicon photovoltaic materials through hydrogen dilution. Nanoscale Res. Lett. 2014, 9. [CrossRef] [PubMed]

28. Ehara, T. The crystalline properties of nitrogen doped hydrogenated microcrystalline silicon thin films. Thin Solid Films 1997, 310, 322-326. [CrossRef]

29. Akiharu, M.; Minoru, M.; Masahiro, Y.; Minoru, K.; Tatsuo, S. Effect of Reduction in Impurity Content for a-Si:H Films. Appl. Phys. Lett. 1991, 59, 2130.

30. Keppner, H.; Meier, J.; Torres, P.; Fischer, D.; Shah, A. Microcrystalline silicon and micromorph tandem solar cells. J. Appl. Phys. 1999, 69, 169-177. [CrossRef]

31. Sakai, H.; Yoshida, T.; Hama, T.; Ichikawa, Y. Effects of Surface Morphology of Transparent Electrode on the Open-Circuit Voltage in a-Si:H Solar Cells. Jpn. J. Appl. Phys. 1990, 29, 630-635. [CrossRef]

32. Lambertz, A.; Grundler, T.; Finger, F. Hydrogenated amorphous silicon oxide containing a microcrystalline silicon phase and usage as an intermediate reflector in thin-film silicon solar cells. J. Appl. Phys. 2011, 109, 113109. [CrossRef]

33. Flikweert, A.J.; Zimmermann, T.; Merdzhanova, T.; Weigand, D.; Appenzeller, W.; Gordijn, A. Microcrystalline thin-film solar cell deposition on moving substrates using a linear VHF-PECVD reactor and a cross-flow geometry. J. Phys. D 2012, 45, 015101. [CrossRef]

34. Meillaud, F.; Shah, A.; Bailat, J.; Vallat-Sauvain, E.; Roschek, T.; Rech, B.; Dominé, D.; Söderström, T.; Python, M.; Ballif, C. Microcrystalline silicon solar cells: Theory and diagnostic tools. In Proceedings of the 4th World Conference Photovoltaic Energy Conversion, Waikoloa, HI, USA, 7-12 May 2006; pp. 1572-1575.

(C) 2016 by the authors; licensee MDPI, Basel, Switzerland. This article is an open access article distributed under the terms and conditions of the Creative Commons by Attribution (CC-BY) license (http:/ / creativecommons.org/licenses/by/4.0/). 